\title{
H1-3 wt Allele
}

National Cancer Institute

\section{Source}

National Cancer Institute. H1-3 wt Allele. NCI Thesaurus. Code C162862.

Human $\mathrm{H} 1-3$ wild-type allele is located in the vicinity of $6 \mathrm{p} 22.2$ and is approximately $1 \mathrm{~kb}$ in length. This allele, which encodes histone H1.3 protein, plays a role in chromosome condensation. 